\title{
Is Liberal Peace Likely in Nuclear Asymmetry?
}

\author{
Jin Myoung Lee
}

\begin{abstract}
This paper mainly aims to address the question of whether liberal peace is likely in situations of nuclear asymmetry. I assume that a non-nuclear state enters into a trade alliance with a nuclear state to obtain security that the nuclear state is capable of offering. I further assume that a nuclear state enters into trade linkages with a non-nuclear state to obtain trade gains. When nuclear and non-nuclear states engage in disputes, the two states lose security or trade gains. Accordingly, while states in nuclear asymmetry are highly conflict-prone, economic ties in nuclear asymmetry could promote peace by promoting the sharing and exchanging of both economic and security gains. Based on these assumptions, I construct primary hypotheses in a situation of nuclear asymmetry and test these during the period of 1950-2001 under analysis by adopting a logit statistical model. The results support that economic relations in situations of nuclear asymmetry have a significant effect in reducing the likelihood of dyadic disputes, but only when the trading linkages are especially valuable and extensively and mutually dependent. To capture negative evidence, I also construct and examine a rival hypothesis that trade linkages in situations of nuclear symmetry are less likely to lead to reduced conflict. Overall, as expected, the results reveal that economic relations in nuclear symmetry have an insignificant effect on conflict.
\end{abstract}

Key Words: militarized conflict, economic interdependence, nuclear asymmetry, peace, trade

$I^{\prime}$ liberal peace likely between the two Koreas in a situation of nuclear asymmetry through economic exchange? On the surface, it may not be refutable that the two Koreas in nuclear asymmetry are highly unlikely to achieve peace. In the logic of nuclear deterrence, the United States and China are in a situation of nuclear symmetry and thus more likely to promote peace, while the two Koreas

*Jin Myoung Lee (jmlee4789@gmail.com) is a lecturer in the Graduate School of International and Area Studies, Hankuk Univ. of Foreign Studies. He received a Ph.D. in political science from the State Univ. of New York at Buffalo. His research has been empirically exploring the determinants of division and reunification of Korea. Examining quantitatively international relations theories at both Northeast Asian and international levels, he has attempted to build a plausible Korean reunification model.

This work was supported by the National Research Foundation of Korea Grant funded by the Korean Government (NRF-2012S1A5B5A07036898).

The Korean J ournal of International Studies Vol.13-1 (April 2015), 29-61.

http://dx.doi.org/10.14731/kjis.2015.04.13.1.29

(c) 2015 The Korean Association of International Studies 
are in a situation of nuclear asymmetry and thus are not. In reality, the current international system consists of a far larger number of nuclear asymmetric relations, such as the situation of the two Koreas, rather than nuclear symmetric relations like the United States and China. Accordingly, it is not surprising that disputes are expected to be more likely as the number of nuclear states increases in the international system (Bueno de Mesquita and Riker 1982).

What if the liberal peace theory is applied to the conflict-prone dyads of nuclear asymmetric countries? In the logic of the liberal peace perspective, what are most central are the economic motives that are assumed to restrict conflict behaviors between countries with significant levels of economic exchange. Those economic motives are tied to economic gains, the learning process of cooperative behavior, or the pressure of the trade-preferred groups derived from economic linkages. In fact, liberals have sought to build a universal and general theory on the pacifying effect of economic interdependence on conflict. Liberal peace theorists, therefore, pay little attention to distinctive features of dyadic relations. Recently, whereas some empirical studies have analyzed the importance of certain contingencies and boundary conditions for the liberal claim (Mansfield and Pollins 2001; Mansfield and Pevehouse 2000), those have rarely addressed whether conflicts are actually less likely between two countries in a situation of asymmetric possession of nuclear weapons. Accordingly, this paper intends to test the likelihood of the liberal peace in situations of nuclear asymmetry by discovering its causal mechanisms.

One of the most salient phenomena after the WWII was the emergence and spread of nuclear weapons in international relations. It was nuclear weapons that terminated World War II, which was the most barbarous war in the human history. In the 1950s, University of Chicago professor Bernard Brodie, America's "original nuclear strategist," said, "The atomic bomb thus far has achieved really great successes; it helped end the Pacific War." (Brodie 1952; Trachtenberg 1989) Nuclear weapons are inconceivably destructive in that they essentially target civilians as well as military facilities. Yet, Brodie also said, "[A]n all-out war with thermonuclear weapons might well be tantamount to national suicide." (Bernard Brodie 1952) That is, the threat value deters war between nuclear states. Accordingly, it could be argued that "nuclear weapons are in fact a tremendous force for peace and afford nations that possess them the possibility of security at reasonable cost." (Waltz 1990, 731) Nuclear weapons purify deterrent strategies by removing elements of defense and war-fighting because only a small number of warheads need to reach their targets (Ibid.), and the mutually destructive outcomes of the use of nuclear weapons completely remove the probability of victory in a war. Therefore, stability and peace between nuclear states rest on the easy 
calculation of one to another (Ibid.).

Much previous empirical research supports nuclear deterrence theory, ${ }^{1}$ which has been quite convincing in its application to conflict relations between the major powers. At the beginning, nuclear weapons were found to have made only a marginal contribution to deterrence (Huth and Russett 1984). It was also found that nuclear powers prevailed in only about half of the deterrence crises cases (Organski and Kugler 1980). In addition, Kugler reported that even having a nuclear monopoly led to a favorable outcome for the nuclear power only half the time (Kugler 1984). In later studies, however, the deterrent roles of nuclear weapons were theoretically clarified and empirically confirmed (Gaddis 1986; Huth 1990; Waltz 1993; Huth and Russett 1993; DeNardo 1995; Zagare and Kilgour 2000; Danilovic 2002). Glaser contended that "during the Cold War, even though the U. S. was highly vulnerable to Soviet nuclear attack, the possibility of the US escalation to strategic nuclear attacks provided the US with a highly effective deterrent."2 In particular, John Mearsheimer has advocated for the deterrent role of nuclear weapons, arguing that a nuclear Germany would make the world a safer place (Mearsheimer 1990).

In contrast, there are some critiques of nuclear deterrence theory. Lebow has pointed out that the major problem with nuclear deterrence theory is that its assumptions, such as rational decision-makers, perfect information, and a politically neutral environment, are too idealistic and therefore not applicable to the real world (Lebow and Stein 1989). In addition, Mueller has argued that nuclear weapons are essentially irrelevant to understanding postwar instability (Mueller 1988; 2010).

While researchers have paid little attention to the likelihood of disputes in conditions of nuclear asymmetry, some have found that disputes in situations of nuclear asymmetry are more likely (Mesquita and Riker 1982; Sagan 1995; Rauchhaus 2009). Bueno de Mesquita and Riker assumed that while conflicts in nuclear symmetry are unlikely due to the fear of retaliation, conflicts in nuclear asymmetry are likely (Mesquita and Riker 1982). When nuclear weapons start to spread to other countries, therefore, nuclear wars increase in number at a decreasing rate. Logically, just after nuclear weapons have proliferated to half the nations in the international system, nuclear wars should begin to decline. There

\footnotetext{
${ }^{1}$ In addition, this realist position was explicitly displayed in the issue of a nuclear DPRK as follows. One nuclear strategist, John Mearsheimer, said, "It might be the best choice for the ROK to be armed with its own nuclear deterrent against nuclear DPRK.” (Korea Joongang Daily 2013).

${ }^{2}$ Glaser (1992). See Coale $(1985,488)$. Coale noted that the United States and the Soviet Union didn't directly engage in military disputes in East and West Europe during the Cold War.
} 
will be no nuclear wars when all the countries of the world possess nuclear weapons (Ibid.). In sum, "given the logic of deterrence, the probability of a rationally calculated use of nuclear weapons is higher when there are pairwise asymmetries in the possession of such weapons than when there is symmetry" (Ibid.). They found that disputes are more likely in situations of nuclear asymmetry than symmetry. They suggested that nuclear weapons should be selectively spread out, particularly to non-nuclear states facing nuclear-armed adversaries. In the organizational perspective, Scott D. Sagan rejected three main assumptions of the rational deterrence framework. 3 In particular, he contended that nuclear asymmetry was highly likely to lead to a preventive war due to the inherent nature of military organizations. ${ }^{4}$ His argument was made based on evidence from the US case. 5 It was also found that dyads in which one state has nuclear weapons were associated with an increased chance of war as well as militarized disputes and conflicts that involve force or limited numbers of fatalities (Rauchhaus 2009).

The consequences of nuclear asymmetry in a dyadic system therefore are not different from that of a zero-sum game in which actors struggle for security. The more likely nuclear states are to promote their own security interests, the more threatened non-nuclear states feel. Accordingly, it is quite obvious that nonnuclear states in an era of nuclear proliferation are unavoidably driven into the most vulnerable security situations. Nuclear asymmetric relations are numerically predominant, the most unprecedented in history, and powerful in significance in shaping current international politics. Despite the inherent vulnerability of nuclear asymmetry defining nearly all relations in the current international system, researchers have rarely paid attention to the likelihood of achieving the so-called liberal peace in such situations of nuclear asymmetry. Undoubtedly it is practically significant to address the question of whether or not liberal peace is likely in nuclear asymmetry.

${ }^{3}$ Sagan (1995) presented two reasons for the major impediments to pure rationality in organizational behavior: a severely bounded form of rationality inherent in large organizations and conflicting goals inherent in complex organizations.

${ }^{4}$ Ibid. Sagan argued that there were five strong reasons to expect that military officers are predisposed to view preventive war in particular in a much more favorable light than are civilian authorities: i) military officers seeing war as inevitable in the long run, ii) training to focus on pure military logic, iii) displaying strong biases favorable to offensive doctrines, iv) tending to plan for war, and v) narrowly focusing on their specific job.

${ }^{5}$ Ibid. For example, during both the Truman and Eisenhower administrations, senior US military officers seriously advocated preventive war options against the Soviet and China and, in both cases, continued favoring such ideas well after civilian leaders ruled against them. In contrast, Waltz maintains that a nuclear state is not likely to initiate a preventive strike against a non-nuclear adversary because it would be hard for a nuclear state to destroy another country's potential for future nuclear development (Waltz 1995, 18). 
Here, employing the concept of security gains generated in nuclear asymmetry, I construct a liberal peace hypothesis that countries with higher levels of economic linkages in nuclear asymmetry are less likely to engage in conflicts. States in nuclear asymmetry are assumed to prefer each other as trading partner because each partner receives different benefits. Economic relations in situations of nuclear asymmetry, therefore, could generate mutually exchangeable benefits. I assume that a non-nuclear state enters into a trade alliance with a nuclear state to obtain security that the nuclear state is capable of offering. When a nuclear state fully expects to maximize sufficient trade gains from its non-nuclear trading partner, it could willingly offer security to its non-nuclear trading partner in order to preserve those trade gains. While nuclear states cannot get security gains, they could still get trade gains. When nuclear and non-nuclear states engage in disputes, those two states can be assumed to lose security or trade gains. Non-nuclear states, of course, are relatively more restricted from conflict escalation with nuclear trading partner. Accordingly, my main argument is that trade linkages in nuclear asymmetry are more likely to reduce conflict than trade in any other dyads, particularly such as dyadic situations of nuclear symmetry. Ultimately, the pacifying effect of interdependence in nuclear asymmetry is more significant than any other dyads.

To test this argument, I analyze the effects of trade exchanges and nuclear asymmetry on military disputes during the period from 1950 to 2001. Trade linkages are measured in three dimensions: trade salience, trade symmetry, and their interactive effects. Our results indicate that trade exchanges in situations of nuclear asymmetry have significant negative effects on the likelihood of disputes, which supports the liberal peace hypothesis.

\section{THE DEBATE ABOUT INTERDEPENDENCE AND CONFLICT}

The liberal peace hypothesis has been considered as one of the most promising ideas to promote peace in international relations. Pursuing to build a universal and general theory, abundant previous research has extensively examined this hypothesis. According to the liberal hypothesis, the increase in bilateral trade is evaluated to further the security relations because the two countries are restricted from conflict behaviors due to the fear of the severance of trade relations. Immanuel Kant viewed that war was a natural phenomenon and peace was created by the will of people. He insisted that because the power of money, which is obtained through commerce, was the most dependable of all the powers, including military, states were ultimately forced to promote peace rather than war (Kant 1957). 
While the liberal hypothesis has not entirely evolved to a unified theory, the majority of empirical studies support it. As a pioneer of quantitative analysis on the effects of trade on conflict, Polachek (1980) found that countries with the greatest levels of bilateral trade volume were involved in the least, and less intense, number of disputes. In addition, he also recognized that trade is an endogenous, predetermined variable. He found that causality still runs from trade to conflict even when accounting for simultaneity (Ibid., 65-66). Analyzing US-Warsaw Pact trade and conflict data during détente, Polachek and Gasiorowski found that total trade significantly led to a greater reduction in Warsaw Pact conflict than in US conflict. These findings implied that the expansion of East-West trade benefited the East more than the West (Gasiorowski and Polachek 1982). Particularly, the authors paid considerable attention to asymmetries in the benefits associated with trade, which were seen as leading to greater conflict reduction on the part of the participant who benefited more. These findings suggest that the reduction in hostilities may frequently take the form of concessions exchanged under linkage diplomacy (Ibid.). The idea that asymmetric benefits in trade exchange could be a source of influence is well addressed in subsequent literature (Gilpin 1987; Keohane and Nye 1989; Kroll 1993). Keohane and Nye conceptualized interdependence in terms of vulnerability and sensitivity. Whereas vulnerability focuses on the costs of breaking relations, sensitivity can be seen as focusing on the costs of maintaining it (Keohane and Nye 1989, 12). According to John A. Kroll, these two concepts are theoretically distinct; therefore, analysis of state interactions must include measures of both, plus independence (Kroll 1993, 322).

In addition to the debate about the theoretical concept of interdependence, Mark J. Gasiorowski started to open the debate about the measure of interdependence particularly in terms of cost-benefit analysis (Gasiorowski 1986). He noted that a country's total trade ratio to its GDP is not an indicator of the costs of interdependence, but rather is only a measure of the benefits of interdependence. He suggested that the costs of interdependence are divided in two categories: vulnerability, which can be measured by a trade partner concentration index and the commodity concentration of exports, and sensitivity, which is measured by short- and long-term capital flows. The results of Gasiorowski's statistical analysis showed that costly trade produces an increase in conflict, while beneficial trade produces a decline in conflict. Testing the realist hypothesis that foreign trade is one of the motives for war, William K. Domke found that high levels of exports are most significantly associated with lower levels of conflict (Domke 1988). Joanne Gowa and Edward D. Mansfield assumed that trade produces security externalities and found that allies trade more with each other than do 
non-allies under bipolarity, but that this relationship disappears under multipolar. The findings imply that trade gains would be utilized to enhance the military power of any country that engages in it (Gowa and Mansfield 1993). Edward D. Mansfield also presented evidence of a liberal hypothesis that international systems that were more open to foreign trade were less likely to engage in military disputes (Mansfield 1994). John R. Oneal, Frances H. Oneal, Zeev Maoz, and Bruce Russett first paid attention to the pacifying effects of trade between warprone dyads. Employing a politically relevant dataset and measuring economic interdependence with the ratio of bilateral trade to GDP, the authors found that trade was a powerful and positive influence for peace, especially among warprone contiguous pairs of states (Oneal, H. Oneal, Maoz, and Russett 1996).

Obviously, focusing on the Kantian 'Triangulating Peace' consisting of trade, democracy, and international organizations, Bruce M. Russett, John R. Oneal, and others represent the clearest statement of the liberal position, the significant empirical findings supporting liberal claims, and the most powerful defense against criticisms of the liberal hypothesis (Oneal and Russett 1997; Russett, Oneal, and Davis 1998). They adopted the weak-link assumption that the likelihood of conflict was primarily a function of the freedom for military action of the less-constrained state. That is, "the less dependent should have greater freedom to initiate conflict because its economic costs would be less and the beneficial influence of trade as communication would be less." (Oneal and Russett 1997, 276) This is consistent with the idea that asymmetric trade relations can be a source of influence (Keohane and Nye 1989; Kroll 1993). Employing politically relevant dyads for the Cold War era, the authors measured economic interdependence while focusing specifically on the country with the lower bilateral tradeto-GDP ratio in the dyad. They found that the pacific benefits of interdependence were evident in all their tests. In the later research (Oneal and Russett 1999), Russett and Oneal expanded the period under analysis to 1885-1992 and employed all possible dyads instead of only those dyads that were politically relevant. As before, the operational index of interdependence was the measure of bilateral trade-to-GDP and the weak link dyad. The results of the analysis provide strong support for the pacifying influence of trade based on the weak-link assumption. Finally, using the entire 1885-1992 set of politically relevant dyads, they evaluated the effect of bilateral trade on conflict. The results of their logit regression analysis showed that interdependence significantly reduced the risks of dispute. ${ }^{6}$ The problem with the weak link measurement was its inability to

\footnotetext{
${ }^{6}$ Russett and Oneal's (2001) major interest was in the democratic peace theory, so in this work one of their main goals was to analyze the combining effects of economic interdependence and democ-
} 
determine whether the less constrained countries were actually initiators or whether they were not within a dyad in which conflict occurs. Recently, Zeev Maoz found that the liberal paradigm is consistently supported in the research.7

Unlike most liberals who attempted to build a universal theory, applying all actors in all times and places, Edward E. Mansfield and B. M. Pollins emphasized the importance of identifying the contingencies and boundary conditions of economic exchange on belligerence (Mansfield and Pollins 2001). First of all, the expansion of commerce is considered as one of the products of political and military struggles throughout history. ${ }^{8}$ In this context, some scholars have found that the interactions between interdependence and domestic coalitions (Solingen 1998) or state institutions (Papayoanou 1996) had influenced a state's propensity to fight. Havard Hegre found that the relationship between trade and conflict was statistically significant only in dyads consisting of two developed countries, implying that the relationship was basically contingent on the level of development (Hegre 2000).

Particularly suggestive was work by Edward D. Mansfield and Jon C. Pevehouse analyzing the effects of bilateral trade flows and preferential trade arrangements (PTAs) on interstate disputes during the Cold War period. Their findings indicated that while trade linkages had little effect on the reduction of disputes between states that did not participate in the same PTA, those linkages have a strong, inverse effect within PTAs (Mansfield and Pevehouse 2000). Christopher F. Gelpi and Joseph M. Grieco found that democratic leaders are more averse than autocratic leaders to initiating military conflicts with trading partners because conflicts could damage commercial ties (Gelpi and Grieco 2008). The authors assumed that democratic leaders relied more heavily on public policy successes, particularly economic growth. Their findings implied that the pacifying effect of trade exchange depended upon the prior presence of democratic institutions of government.

The strongest challenges to the liberal proposition emerged with the introduction of a new operational index of interdependence which consisted of three dimensions: trade salience, symmetry, and their combined effect (Barbieri 1996;

racy on military conflicts.

${ }^{7}$ Maoz divided interdependence in two types: economic and strategic. He assumed that whereas most liberals regarded both strategic and economic interdependence as a source of peace, realists expected strategic interdependence to reduce the likelihood of dyadic conflict (2009, 225-226).

${ }^{8}$ Mansfield and Pollins argued that "commerce has expanded during the past four centuries within two different policy contexts: initially embedded in a more state-directed and imperialist environment during the mercantilist era and later within a more liberal economic regime" (2001, 844). 
Ibid., 2002). Katherine Barbieri found that a high level of economic linkages, particularly asymmetric trade, was rather more likely to increase disputes than had been predicted by realists. Oneal and Russett, however, questioned her control variables and measures of interdependence (Oneal and Russett 1999). After replicating her specifications with some changes, they found no relationship between interdependence and peace among all dyads. Yet, they found a significant pacifying effect of trade on disputes among politically relevant dyads. When controlling for temporal dependence and their preferred measures of interdependence and proximity, they found increasingly strong support for the liberal position. Nonetheless, Barbieri's measures have been critical in exploring the relationship between interdependence and conflict.

In addition, developing new estimation techniques to correct statistical problems caused by duration dependence, Nathaniel Beck and his associates found that trade is not considerably associated with disputes. 9 When controlling for temporal dependence, however, later research showed that higher levels of trade dependence dramatically reduced the odds of conflict, particularly among nondirected dyads (Bennett and Stam 2000).

In testing the liberal peace hypothesis, simultaneity has been one of the major issues. Accordingly, some scholars have found that there was a simultaneity problem in the relationship between interdependence and conflict (Reuveny and Kang 1998; Ibid., 1996; Reuveny 2003). In particular, employing a statistical technique to control the simultaneity problem, some other challenging research has indicated that disputes could cause economic interdependence, not the other way around (Keshk, Pollins, \& Reuveny 2004; Kim \& Rousseau 2005). The main problem with their findings was the lack of a theoretical grounding that could account for a simultaneity bias that could explain the history before but not after World War II. Recently, this challenging research has been criticized for implying some serious model specification bias (Hegre, Oneal and Russett 2010). When the proximate variable was operationalized as a continuous variable of distance and the dyad size was included in the model, it was found that economic interdependence has significant impact on disputes, and vice-versa.

In sum, scientific research on the liberal peace hypothesis has made crucial progress over the last 30 years in terms of defining the causal mechanisms, measurement, model specification, and the use of advanced statistical techniques,

\footnotetext{
${ }^{9}$ Beck, Katz, and Tucker's (1998) logit model is based on an assumption of independent observations. However, when a militarized interstate dispute data set was utilized, this assumption was violated because of the dependence and rarity of events. To address these problems, the authors suggested the use of peace-years and three cubic splines variables from the BTSCS algorithm.
} 
although the applications of these new ideas still remain open to question. In addition, the majority of empirical studies have supported the core liberal claim. However, the liberal peace hypothesis has not evolved into a unified theory, as shown in the competing findings.

\section{THE LIBERAL PEACE AND NUCLEAR ASYMMETRY}

Largely ignored in the empirical research on the liberal peace hypothesis has been the pacifying effect of economic exchange within conflict-prone dyads such as what has been seen in situations of nuclear asymmetry as discussed in this paper. In that regard, particularly important is the research by John R. Oneal and his associates, indicating that higher levels of economic exchange inhibited disputes, especially between contiguous states (Oneal, H. Oneal, Maoz, and Russett 1996). In this study, the authors first showed that geographic proximity was the most powerful among all other variables to explain conflict. Then they evaluated the effect of trade on conflict only within contiguous pairs of states, where the potential for conflict was greatest, controlling for all other variables. The implications of these findings were quite straightforward: economic interdependence significantly counteracts the negative influences of the conflict-prone variable (Ibid.). Obviously, nothing can be theoretically and practically more useful than the liberal peace claim between conflict-prone states.

Nevertheless, previous empirical studies have paid little attention to the likelihood of cultivating trade relationships (liberal peace) between adversaries, previously hostile countries, enduring rivalries or conflict-prone dyads. Rather, some studies have proposed that economic relations were influenced by states' security interests, as well as by economic concerns. That is, in addition to economic and material concerns, such as price and quality, the utility of importers and exporters is affected by the political and security concerns of managing risk, such as the desire to reward friends, punish adversary, and minimize the risk of economic disruption (Pollins 1989a; Pollins 1989b). Gowa and Mansfield (1993), and Gowa (1994) have shown that states are more apt to trade with allies than non-allies. They assumed that the economic gains arising from commercial relation were also the source of the security externalities that can either impede or facilitate it. A state tends to trade with an ally because the economic gains arising from commercial relations could be used to threaten its security, and allies ostensibly do not pose such security threats. In contrast, trade with an ally produces a positive externality. For example, from this point of view it could be argued that, after World War II, the United States deliberately opened its markets to Japan to 
facilitate Japan's revival as a prosperous and democratic ally.

These ideas, however, can't fully explain the best examples in favor of the liberal peace theory, such as the formation of the European Economic Community, Richard Nixon's opening to China, Willy Brandt's Ostpolitik, and Henry Kissinger's détente with the Soviet Union (Mansfield and Pollins 2001). Furthermore, as previously illustrated, these ideas are quite far from the theoretical usefulness of the liberal peace claim. Obviously, the most implicit assumption of the liberal peace claim is that trade with an adversary may not produce a security diseconomy. ${ }^{10}$

If so, under what conditions would a liberal peace be likely in a situation of nuclear asymmetry, which clearly involves conflict-prone relations? In other words, why do states in nuclear asymmetry choose to enter trade alliances, thereby leading to a reduced probability of conflict? The previous empirical research on alliance formation shows that countries tend to select allies that are opposite to them in asymmetry in power (Altfeld 1984; Morrow 1991) or regime types (Simon and Gartzke 1996). Altfeld (1984) has mainly argued that alliance formation is the product of trade-offs between security and autonomy, and between armaments and welfare, as shown in the linear budget constraint for most economists. This implies that the majority of alliances are very asymmetric, showing a combination of a major and several minor powers rather than collections of powerful nations alone. Morrow (1991) has also found that asymmetric alliances in size and capabilities are easier to form and last longer than symmetric alliances because each side receives different benefits. In asymmetric alliances, the stronger partner gains autonomy and provides security to the lesser partner (930). He found that the majority of alliances are asymmetric during his period under analysis. Simon and Gartzke assumed the bias of politically dissimilar states in favor of selecting each other as alliance partner was because partners may receive something like gains from trade to offer each other beyond security aggregation (Simon and Gartzke 1996). Furthermore, "politically asymmetric alliances have the advantage of combining the complementary qualities of democratic and autocratic partners" (Ibid.). They found that while autocratic nations prefer to ally with other autocratic regimes, democracies are less likely to ally with one another. They concluded that this strong tendency to prefer alliances with dissimilar regimes was due to gains from trade within the alliance.

In the liberal position, these findings of asymmetric alliance formation were

${ }^{10}$ Barbieri and Levy (2001) statistical analysis showed that in most cases war does not have a significant impact on trading relationships, rejecting the realist position that concerns about security externalities lead to a reduction or elimination of trade between enemies. 
applied in the research on the pacifying effects of economic linkages in large and small countries by Polachek, Robst, and Chang (1999). Their main argument was that trade linkages in situations involving asymmetry in economy size led to decreased conflict. Along with the findings of asymmetric alliance formation in power asymmetry, the authors assumed that small countries have an incentive to join trade alliances with large countries due to the security that a large country can offer. Theoretically, in addition to this security gain from trade with large countries, small countries have markedly more gains in such areas as domestic consumption and an increase in investment. In short, the authors assumed that large countries entered into trade linkages with small countries to receive trade gains, while small countries entered into trade relations with large countries to gain security. Accordingly, when being conflictual with a large trading partner, small countries are more restricted in terms of conflict escalation because they could lose security as well as trade gains. They found that a small country increasing trade with a large target reduced conflict more than a small country increasing trade with a small target.

A serious question in Polachek, Robst, and Chang's empirical test was the operational index of the large and small countries with the differences in GDP size. Are large countries, as measured by the size of their GDP, substantially capable of offering security to their relatively smaller trading partners? While it could be true that the United States was capable of providing reliable security to the Republic of Taiwan, it would be hard to believe that Japan would be capable of such provision to Taiwan. Hence, size asymmetry in economies would not capture those cases where trade ties lead to greater security.

Here, employing the concept of security gains generated in asymmetric relations in power (Altfeld 1984; Morrow 1991), regime type (Simon and Gartzke 1996), or economy size (Polachek, Robst, and Chang 1999), I further develop the idea of a pacifying effect of interdependence in situations of nuclear asymmetry. I assume that states in nuclear asymmetry prefer each other as trading partner because each partner receives different benefits. In addition, economic linkages in nuclear asymmetry could generate two mutually exchangeable benefits: security gains for non-nuclear states and trade gains for nuclear states. Economic exchanges in nuclear asymmetry could lead non-nuclear states to gain the security benefits that nuclear states can offer. While nuclear states cannot get security gains, they could still get trade gains. When nuclear and non-nuclear states engage in disputes, both states lose security and/or trade gains. Non-nuclear states, of course, are relatively more restricted from the conflict with nuclear trading partner because conflicts could damage commercial gains as well as security gains for the non-nuclear states. Accordingly, I argue that trade linkages in 
nuclear asymmetry are more likely to reduce conflict than nuclear symmetry. Ultimately, the pacifying effect of interdependence in nuclear asymmetry is more significant than any other dyads.

I assume that a non-nuclear state enters into trade alliance with a nuclear state to obtain security that the nuclear state is capable of offering. Accordingly, the more nuclear states it moves into trade linkages with, the more advantageous security gains the non-nuclear state could acquire. To maximize its security, a non-nuclear state could attempt to form trade alliances with more nuclear states, practically with all the nuclear states in the international system. In addition to security gains, a non-nuclear state could take either trade gains from its larger nuclear trading partner or economic leverage to pressure its smaller nuclear trading partner. If a non-nuclear state is larger than its nuclear trade partner in size, a non-nuclear state would willingly enter into economic relations with the nuclear state because that economic relationship would provide a non-nuclear state with economic leverage to pressure the nuclear state in the short term, as well as security gains in the long term. In the long term, the non-nuclear state could expect to achieve security gains that its nuclear trading partner can offer. If a nonnuclear state is smaller than its nuclear trading partner in size, the non-nuclear state willingly gets into economic ties with a larger nuclear state because the smaller non-nuclear state could obtain economic gains in the short run, as well as security in the long run. "An increase in the price of exports could have relatively more considerable direct impact on the domestic economy of a small rather than that of a large" non-nuclear state (Ibid.).

I further assume that a nuclear state enters into trade linkages with a nonnuclear state to obtain trade gains. Nowadays most states tend to comply with the rules of the international trade regime. In order to nurture its own wealth, power, and welfare, a state has essentially two options: increase international trade or pursue territorial expansion (Rosecrance 1986). For example, since WWII Japan has converted from a strategy of military invasion to one of trade promotion as a means to achieve wealth (Mueller 2009). "Nowadays Japan would aim at the military invasion to obtain raw materials and petroleum if it were in 1930s, but it uses international trade." (Ibid., 628) Likewise, nuclear states prefer international trade to military engagement with non-nuclear states. For example, China gave up its commitment to a world communist revolution in 1970s. Since then, the United States has gradually consolidated its relationship with China as though the PRC were its ally (Mueller 2004). In addition, while nuclear weapons are unprecedentedly destructive, they are most valuable only when not used. That is, nuclear weapons are most useful only when used for political means, not military, to achieve the major goals of nuclear states. In short, when a nuclear state fully 
expects to maximize significant enough trade gains from its non-nuclear trading partner, it could willingly offer security to its non-nuclear trading partner in order to preserve those trade gains. Accordingly, when nuclear and non-nuclear states engage in disputes, both states can suffer security or trade losses. Non-nuclear states, of course, lose both security and trade gains. Non-nuclear states, therefore, are more reluctant to engage in conflict with their nuclear trading partners.

Consequently, it is contended that trade linkages in situations of nuclear asymmetry reduce conflict more than trade in situations involving nuclear symmetry. Ultimately, the pacifying effect of international interdependence in the nuclear asymmetry would be more significant than any other dyads.

Accordingly, the pacifying effects in situations of nuclear asymmetry could be hypothesized as follows:

H1: Economic interdependence in nuclear asymmetry is more likely to lead to decreased conflict.

To capture any negative evidence for the liberal hypothesis in nuclear asymmetry, I also construct and examine a rival hypothesis that the expansion of trade linkages in nuclear symmetry is less likely to inhibit conflict. That is, I assume that the intensive and extensive economic ties in a trade partnership involving countries in a situation of nuclear symmetry (either both countries have nuclear weapons or neither does) could not generate special incentives such as security gains. Hence, there would be no significant effect in decreasing the likelihood of dyadic disputes between them. A rival hypothesis has been constructed as follows:

$\mathrm{H} 2$ : Economic interdependence in a situation of nuclear symmetry is less likely to lead to reduced conflict.

\section{RESEARCH DESIGN}

The primary goal of this research is to quantitatively examine whether economic interdependence in nuclear asymmetry is associated with disputes. The unit of analysis is dyad/year and the period under analysis is 1950-2001, which is based on the accessibility of data. ${ }^{11}$ To test hypotheses, a cross-sectional pooled time

\footnotetext{
${ }^{11}$ So far, the most recent data for MIDs, which is the dependent variable in this paper, is just available up to 2001 when we utilize the Eugene Expected Utility Generation and Management Program in order to construct data specified for this research.
} 
series data set is established. In addition, I employ all dyadic samples rather than using only politically relevant samples. A recent study found that politically relevant samples significantly bias the results of the statistical analysis on the relationship between interdependence and conflict. ${ }^{12}$ The Eugene Expected Utility Generation and Management Program is utilized to construct the directed dyadyear data (Bennett and Stam 2000). In tmy research model, the dependent variable is the onset of militarized interstate disputes (MIDs). The independent variable is economic interdependence, which is operationalized along three dimensions of trade: i) trade salience, ii) trade symmetry, and iii) interdependence, which addresses their interaction terms. Control variables consist of i) dyad size, ii) proximity, iii) regime type, iv) relative capability, v) military alliance, and vii) post-Cold War. Accordingly, the model that will be tested below is summarized in the equation:

Onset of MID $=\alpha+\beta 1^{*}($ trade salience $)+\beta 2 *($ trade symmetry $)+\beta$ $3^{*}$ salience ${ }^{*}$ symmetry $+\beta 4^{*}$ dyad size $+\beta 5^{*}$ relative capability $+\beta^{*}$ regime type + $\beta 7^{*}$ contiguity $+\beta 8^{*}$ alliance $+\beta 9^{*}$ post-Cold War $+\beta 10^{*}$ peace year $+\beta 11^{*}$ spline $1+\beta 12^{*}$ spline $2+\beta 13^{*}$ spline $3+\varepsilon$

Dependent variable: Onset of militarized interstate disputes The dependent variable is the outbreak of militarized interstate disputes, which involves the initiation of disputes. The dataset of the dependent variable is derived from the Dyadic Militarized Interstate Disputes (MID) Data of the Correlates of War Project. ${ }^{13}$ Accordingly, ongoing disputes are excluded from the MID dataset. The dependent variable is dichotomous. When any one of threat, display, use of force, or war occurs (Jones, Bremer, and Singer 1996), it is coded as 1, otherwise o.

Independent variable: Economic interdependence Economic exchange is measured by bilateral trade volume. The operational indices of economic interdependence are three dimensions of trade: salience, symmetry, and their interaction term, as suggested by Barbieri (Katherine Barbieri 1996; 2002). The trade data is transformed with the Expanded Trade Data suggested by Kristian Skrede Gleditsch (Gleditsch 2002), which could considerably reduce the missing data for

\footnotetext{
${ }^{12}$ Benson (2005) examined the effects of politically relevant dyads on the relationship between trade linkages and conflict. In fact, a politically relevant sample includes at least one major power by $70 \%$ and at least one very large economy to an abnormally high proportion (Ibid., 117). She found that politically relevant dyads are significantly biased toward major powers, always showing a negative, significant effect of salient trade on disputes (Ibid., 130).

${ }^{13}$ Available at <http://www.correlatesofwar.org/> (accessed on 4 July 2014).
} 
the Communist countries just after WWII.

Trade salience Trade dependence of State $i$ on $j$ is measured by using the trade share of total bilateral trade with State $j$ of State $i$ 's GDP. Trade salience of State i and $j$ is the geometric mean of State $i$ and State $j$ 's bilateral dependence

$($ Salience $i j=\sqrt[2]{\{(\text { Importsij+Exportsij) }) / \text { GDPi }\} \times\{(\text { Importij+Exportsij }) /(G D P j\})}$

The value of trade salience ranges from o to 1 . If it is closer to 1 , it could be interpreted that the importance of economic relations in the dyad is high, otherwise low.

Trade symmetry Barbieri hypothesizes that conflict is less likely between states with symmetrically dependent trade linkages. Trade symmetry is 1 minus the absolute value of the difference in trade salience $i$ and $j$. If it is closer to 1 , it could be interpreted as symmetric, otherwise asymmetric in a dyadic trade relationship. The index of trade symmetry represents how mutually beneficial each side in a dyad is from bilateral trade (Symmetry $i j=1-\mid$ Dependence $_{i}$ - Dependence $j \mid$ ).

Interdependence This operational index is the interaction terms of trade salience and symmetry. In general, interaction terms could imply high multicollinearity. Hence, an attempt is made to reduce the expected multicollinearity by multiplying the standardized trade salience and symmetry (Friedrich 1982). In principle, this value would be higher when both trade salience and symmetry are high. If either the trade salience or symmetry is zero, or closer to zero, the trade linkage in a dyad could be interpreted as unilateral subjective relations. In theory, the concept of trade symmetry and the interaction term of trade salience and symmetry are not suggested in the liberalism.

Nuclear states The data on nuclear states were collected based on the guidelines suggested by Erik Gartzke and Matthew Kroenig (2009), and Gartzke and Dong-Joon Jo (2007). According to those authors, for a state to be judge 'nuclear' requires both nuclear development programs and a substantial number of nuclear warheads. Accordingly, the Ukraine, Kazakhstan, and Belarus in 1992 are not coded as nuclear states because those countries didn't have viable nuclear development programs. ${ }^{14}$ In general, conceptually it is not controversial that the five major powers are identified as nuclear states. Some countries, however, are controversial in identifying when the starting or ending date for the possession of nuclear weapons was. First, for countries that are assumed to possess nuclear weapons in secret, the starting date of possession is defined by the year when the possession of nuclear weapons was confirmed by related documents. Second, the

14 Bennett and Stam (2004) categorized those countries as nuclear states. 
end date of the possession of nuclear weapons was defined by the year when the supreme decision-maker completely dismantled those nuclear weapons. According to these criteria, 10 countries having nuclear capabilities are identified as 'nuclear states': the US from 1945, Russia from 1949, the U.K. from 1952, France since 1960, China from 1964, Israel from 1966, South Africa between 1979 and 1991, India from 1988, Pakistan from 1988, and the DPRK since 2006. This variable is dichotomous; when any state is identified as a nuclear state, it is coded as 1 , otherwise 0 .

Dyadic size Many previous studies have found that gross domestic product correlates significantly with conflict (Benson 2005; Hegre 2004; Mansfield and Pevehouse 2000; and Gasiorowski 1986). Accordingly, the effect of this variable is controlled in the model. This variable is operationalized by the sum of the GDP of the two countries in a dyad.

Contiguity If two countries in a dyad share common borders or are less than 400 miles away, they are defined as proximate and coded as 1 , otherwise 0 . Geographical contiguity has been found significant in increasing the likelihood of disputes (Hegre, Oneal and Russett 2010; Oneal, Maoz, and Russett 1996; Bremer 1992; Siverson, and Starr 1991; Starr and Most 1976).

Joint democracy It has been demonstrated that disputes are less likely between countries with high joint levels of democracy (Bennett and Stam 2004; Maoz and Russett 1993; Dixon 1994; and Bremer 1992). In particular, comparative analysis of international relations shows that conflict between democratic political systems is minimal (Bennett and Stam 2004, 24). The joint level of democracy is measured using the Polity IV Data (Joint Democracy $i j=\left\{\left(\right.\right.$ Democracy $_{i}-$ Autocracy $\left.\left._{i}+10\right) / 2\right\} \times\{($ Democracyj-Autocracyj+10) $/ 2\})$.

Alliance If two states in a dyad are engaged in a mutual pact, a neutral pact, or entente, the dyad is coded as 1 , otherwise 0 . While disputes are less likely between countries in an alliance, its pacifying effect is still controversial. Alliance data is based on the COW Formal Alliance data set. ${ }^{15}$

Relative capabilities Most previous conflict studies control for the variable of relative power (Kugler and Lemke 1996; Bremer 1992; Mesquita and Lalman 1992; and Organski and Kugler 1980). On the contrary to the expectations of balance of power theory, most research has found disputes less likely in dyads with more asymmetric power relations. The capability data is taken from the natural $\log$ of the sum of the capabilities of the two countries in a dyad which are derived from the COW Composite Indicator of National Capabilities Index. ${ }^{16}$

\footnotetext{
${ }^{15}$ Available at <http://www.correlatesofwar.org/datasets.htm> (accessed on 11 October 2014).

${ }^{16}$ Available at <http://www.correlatesofwar.org/> (accessed on 4 December 2014).
} 
Post-Cold War While the number of disputes varies by time and across regions since the end of the Cold War, it could generally be considered as a declining pattern. It was reported that during the 1990-1997 period after the Cold War, interstate wars significantly declined compared to the previous 10-year period (Sarkees, Wayman, and Singer 2003). The post-Cold War period is coded as 1, otherwise 0 .

\section{ANALYSIS AND EVALUATION}

Logit regression analysis is used because the dependent variable is the onset of disputes. In general, there are two problems in applying the logit statistical model to analyze interstate militarized disputes. One of most important assumptions of the logit statistical model is the independence of events. This assumption, however, could be easily violated because disputes could, by their nature, have a strong impact either on one another or follow-up disputes. The other problem is that the onset of disputes is relatively quite rare. To address these problems, the duration dependence technique suggested by Beck, Katz and Tucker (1998) is employed through the use of the variable peace-years and three cubic splines variables from the BTSCS algorithm. The logit model is nonlinear, so no single method of interpretation can lead us to fully describe the relationship between a variable and the outcome. I present the factor change in the odds as shown in Table 1. ${ }^{17}$

In order to examine whether the distinctions of economic ties in nuclear symmetry and symmetry affect the conflict propensity of dyadic relations, I conducted four separate logistic regression analyses. Those four logit models mainly evaluate the effect of: (1) economic linkages in all dyads, nuclear asymmetric dyads and symmetric dyads in Model 1, (2) economic relations in nuclear symmetry in Model 2, (3) economic ties in nuclear asymmetry in Model 3, and (4) economic relations in all dyads, in nuclear asymmetry and symmetry in Model 4. In particular, it is Model 4 which addresses this paper's primary research question of

\footnotetext{
${ }^{17}$ In general, there are two methods of interpreting the results of the logit analysis, either as a discrete change in the probabilities or as a factor change in the odds (Long 1997, 151). These two methods are complementary. The change in probability is a useful way to assess the magnitudes of effects in the logit model. Yet, measures of discrete change do not indicate the dynamics among the dependent outcomes (Ibid., 168). The factor change in the odds can answer the question of the dynamics among the dependent outcomes. Of course, the interpretation of each odds ratio is quite simple (Ibid., 168-169). The reason why I do not present the change in the probability is that it is quite complicated to calculate the change in the probability on the combining effect of trade salience and symmetry.
} 
whether interdependence in nuclear asymmetry and symmetry inhibits conflict. Model 4 examines the separate effects of economic ties in nuclear asymmetry and symmetry on disputes. I assume that each trade relationship in nuclear asymmetry and symmetry may independently affect disputes. The absence of either variable may lead to different effects on disputes than that which would exist if only either one of them were present. Finally, however, it turns out that trade linkages in nuclear symmetry do not affect disputes significantly.

Table 1. Duration Dependent Logits and Onset of Dyadic Disputes: 1950-2001

\begin{tabular}{|c|c|c|c|c|}
\hline Variables & Model 1 & Model 2 & Model 3 & Model 4 \\
\hline \multicolumn{5}{|l|}{ 1) All dyads } \\
\hline - Salience & $\begin{array}{l}-13.193^{\star \star \star} \\
(2.722)\end{array}$ & $\begin{array}{l}-12.933^{\star * *} \\
(2.693)\end{array}$ & $\begin{array}{l}7.651^{* *} \\
(2.759)\end{array}$ & $\begin{array}{l}-6.371^{*} \\
(2.714)\end{array}$ \\
\hline - Symmetry & $\begin{array}{l}-1.995^{\star \star} \\
(0.627)\end{array}$ & $\begin{array}{l}-1.940 * * \\
(0.625)\end{array}$ & $\begin{array}{l}-2.967^{* * *} \\
(0.783)\end{array}$ & $\begin{array}{l}-3.008^{* * *} \\
(0.8)\end{array}$ \\
\hline - Interdependence & $\begin{array}{l}-2.660^{* *} \\
(0.808)\end{array}$ & $\begin{array}{l}-2.654^{* *} \\
(0.796)\end{array}$ & $\begin{array}{l}1.115 \\
(0.981)\end{array}$ & $\begin{array}{l}1.716 \\
(1.011)\end{array}$ \\
\hline Nuclear symmetry dyads & $\begin{array}{l}1.559^{* \star \star} \\
(0.145)\end{array}$ & $\begin{array}{l}1.755 \\
(27.391)\end{array}$ & & $\begin{array}{l}3.246 \\
(27.197)\end{array}$ \\
\hline Nuclear asymmetry dyads & $\begin{array}{l}.836^{\star * *} \\
(0.077)\end{array}$ & & $\begin{array}{l}-2.993^{*} \\
(1.213)\end{array}$ & $\begin{array}{l}-2.657^{*} \\
(1.216)\end{array}$ \\
\hline \multicolumn{5}{|l|}{ 2) Nuclear symmetry } \\
\hline - Salience & & $\begin{array}{l}763.204 \\
(2039.758)\end{array}$ & & $\begin{array}{l}641.840 \\
(2064.86)\end{array}$ \\
\hline - Symmetry & & $\begin{array}{l}-0.557 \\
(27.438)\end{array}$ & & $\begin{array}{l}-1.358 \\
(27.242)\end{array}$ \\
\hline - Interdependence & & $\begin{array}{l}-890.186 \\
(2047.667)\end{array}$ & & $\begin{array}{l}-774.877 \\
(2072.506)\end{array}$ \\
\hline \multicolumn{5}{|l|}{ 3) Nuclear asymmetry } \\
\hline - Salience & & & $\begin{array}{l}71.796^{* * *} \\
(15.999)\end{array}$ & $\begin{array}{l}70.585^{\star * *} \\
(15.823)\end{array}$ \\
\hline - Symmetry & & & $\begin{array}{l}3.704^{\star *} \\
(1.221)\end{array}$ & $\begin{array}{l}3.659^{* *} \\
(1.224)\end{array}$ \\
\hline - Interdependence & & & $\begin{array}{l}-123.041^{* * *} \\
(19.598)\end{array}$ & $\begin{array}{l}-122.244^{* * *} \\
(19.428)\end{array}$ \\
\hline Major power & $\begin{array}{l}1.057^{* \star *} \\
(0.08)\end{array}$ & $\begin{array}{l}1.685^{\star * *} \\
(0.052)\end{array}$ & $\begin{array}{l}1.390^{* * *} \\
(0.072)\end{array}$ & $\begin{array}{l}1.089^{* * *} \\
(0.078)\end{array}$ \\
\hline Relative capabilities & $\begin{array}{l}-1.459^{* * *} \\
(0.099)\end{array}$ & $\begin{array}{l}-1.425^{\star * \star} \\
(0.099)\end{array}$ & $\begin{array}{l}-1.670^{* * *} \\
(0.098)\end{array}$ & $\begin{array}{l}-1.515^{\star * \star} \\
(0.1)\end{array}$ \\
\hline Dyad size & $\begin{array}{l}1.78 \mathrm{e}-13^{\star * *} \\
(1.66 \mathrm{e}-14)\end{array}$ & $\begin{array}{l}2.05 \mathrm{e}-13^{* * *} \\
(1.66 \mathrm{e}-14)\end{array}$ & $\begin{array}{l}2.13 e-13^{\star * *} \\
(1.57 e-14)\end{array}$ & $\begin{array}{l}1.81 \mathrm{e}-13^{* * *} \\
(1.68 \mathrm{e}-14)\end{array}$ \\
\hline Contiguity & $\begin{array}{l}2.928^{* * *} \\
(0.043)\end{array}$ & $\begin{array}{l}2.956^{* * *} \\
(0.043)\end{array}$ & $\begin{array}{l}2.946^{* * *} \\
(0.043)\end{array}$ & $\begin{array}{l}2.917^{* \star *} \\
(0.043)\end{array}$ \\
\hline
\end{tabular}




\begin{tabular}{lllll}
\hline Variables & Model 1 & Model 2 & Model 3 & Model 4 \\
\hline Alliance & 0.004 & -0.000 & -0.021 & -0.035 \\
& $(0.019)$ & $(0.018)$ & $(0.019)$ & $(0.019)$ \\
Joint democracy & $-.009^{* * *}$ & $-0.009^{* * *}$ & $-0.009^{* * *}$ & $-0.008^{* * *}$ \\
& $(0.001)$ & $(0.001)$ & $(0.001)$ & $(0.001)$ \\
Post-Cold War & -0.019 & -0.038 & -0.066 & -0.041 \\
& $(0.048)$ & $(0.048)$ & $(0.048)$ & $(0.048)$ \\
Peace-year & $-.396^{* * *}$ & $-0.399^{* * *}$ & $-0.398^{* * *}$ & $-0.396^{* * *}$ \\
& $(0.013)$ & $(0.023)$ & $(0.013)$ & $(0.013)$ \\
spline1 & $-.003^{* * *}$ & $-0.003^{* * *}$ & $-0.003^{* * *}$ & $-0.003^{* * *}$ \\
spline2 & $(0.000)$ & $(0.000)$ & $(0.000)$ & $(0.000)$ \\
& $.001^{* * *}$ & $0.002^{* * *}$ & $0.002^{* * *}$ & $0.001^{* * *}$ \\
spline3 & $(0.000)$ & $(0.000)$ & $(0.000)$ & $(0.000)$ \\
& $-.000^{* * *}$ & $-0.000^{* * *}$ & $-0.000^{* * *}$ & $-0.000^{* * *}$ \\
Constant & $(0.000)$ & $(0.000)$ & $(0.000)$ & $(0.000)$ \\
\hline Observation number & $-2.798^{* * *}$ & $-2.821^{* * *}$ & $-1.834^{*}$ & $-1.712^{*}$ \\
LR chi2(14) & $(0.624)$ & $(0.622)$ & $(0.786)$ & $(0.802)$ \\
Prob> chi2 & 846626 & 846626 & 846626 & 846626 \\
Log likelihood & 12051.15 & 11955.22 & 12044.94 & 12171.09 \\
Pseudo R2 & 0.00 & 0.00 & 0.00 & 0.00 \\
\hline Each & -15685.00 & -15732.97 & -15688.11 & -15625.03 \\
& 0.2775 & 0.2753 & 0.2774 & 0.2803 \\
\hline
\end{tabular}

Each column consists of the coefficient estimator (first line) and the standard error (second line) of each variable. ${ }^{*} \mathrm{p}<0.05,{ }^{* *} \mathrm{p}<0.01,{ }^{* * *} \mathrm{p}<0.001$

Overall, the results of the statistical analysis show that economic linkages in situations of nuclear asymmetry have a powerful impact on disputes, varying in their directions and significance levels. Evidence supportive of the primary hypothesis in nuclear asymmetry was revealed only in the high levels of economic relations, which significantly reduced the likelihood that dyads engaged in militarized disputes. Yet, neither trade salience nor symmetry alone in nuclear asymmetry was rather more likely to increase the likelihood of disputes. Economic relations in nuclear symmetry had a statistically insignificant impact on the likelihood of disputes, varying in their directions, supporting the rival hypothesis that economic relations in nuclear symmetry is less likely to lead to reduced conflict. Hence, I could cautiously conclude that a liberal peace is more likely in nuclear asymmetry than nuclear symmetry because economic linkages in nuclear asymmetry could generate the kind of security that nuclear trading partners can offer, but this was not the case in nuclear symmetry.

Firstly and most importantly, Model 4 addresses the primary research question 
of whether trade linkages in nuclear asymmetry or symmetry inhibit conflict. Model 4 provides strong evidence of the importance of considering the effects of economic ties in nuclear asymmetry on disputes. When economic relations in nuclear asymmetry are taken into account in Model 4, the pure effects of those in all dyads on disputes are significantly disrupted. In all dyads, the coefficient for interdependence $(\beta=1.176)$, the combined effect of salience and symmetry reverses its sign from that observed in Model $1(\beta=-2.66)$ and $2(\beta=-2.654)$, and loses statistical significance. The coefficients for salience $(\beta=-631)$ and symmetry $(\beta=-$ 3.008) remain negative with statistical significance levels similar to those observed in Model 1 and 2. In addition, the coefficient for nuclear asymmetric dyads ( $\beta=-2.657)$ turns to a negative sign, conversely, from that observed in Model 1 ( $\beta=.836)$, while that for nuclear symmetric dyads $(\beta=3.246)$ remains positive with the complete disappearance of its statistical significance.

Particularly, in nuclear asymmetry, direct evidence to support the primary hypothesis of this paper postulates that outstanding trade linkages are more likely to lead to reduced conflict than other types of trade linkages. Surprisingly, the results from Model 4, however, show that, rather than hindering disputes, salient trade linkages in nuclear asymmetry are more conflict-prone than other types of linkages or those in situations of nuclear symmetry, contradicting the primary hypothesis of the liberal argument. The coefficient for salience in nuclear asymmetry ( $\beta=70.585$ ) is statistically significant and positive. Similarly, the coefficient for salient trade linkages in nuclear symmetry $(\beta=641.840)$ is positive, but not even statistically significant. By contrast, the coefficient for salient trade relationships in all dyads $(\beta=-6.371)$ is statistically considerable and negative. Hence, in nuclear asymmetry, the expansion of trade ties alone doesn't promote peace, appearing rather to bring about increased tensions.

In contrast to the liberal argument, as shown in Model 4, symmetrical trade ties in nuclear asymmetry are more likely to increase disputes, as noted in the statistically significant and positive coefficient $(\beta=3.659)$. Obviously, symmetrical trade ties in nuclear asymmetry are quite distinctive, and more conflict-prone than otherwise, as shown in the statistically significant and a negative coefficient for symmetrical cases in all dyads $(\beta=-3.008)$ or insignificant and a negative coefficient for symmetrical cases in nuclear symmetry $(\beta=-1.358)$. Just like important trading relationships, the balance of dependence alone in nuclear asymmetry seems insufficient to promote peace and rather would add a boost to increased military tensions.

Surprisingly, Model 4 shows that in nuclear asymmetry, while extensive and mutual dependence lead to increased tension as either one increases, their interactive effect reveals that high levels of interdependence significantly reduce the 
likelihood that dyads would engage in militarized disputes, which supports the liberal hypothesis. The statistically significant and negative coefficient for interdependence in nuclear asymmetry ( $\beta=-122.244)$, as indicated in Model 4, manifests hard evidence that interdependence in nuclear asymmetry, which is the combined effect of extensive and mutual dependence, promotes peace. Its strength in nuclear asymmetry to restrict the probability of disputes is quite significant compared to that in nuclear symmetry, as noted in its insignificant and negative coefficient ( $\beta=-774.877$ ) in Model 4 . In fact, the coefficient for interdependence in all dyads ( $\beta=1.716)$, rather, is positive and statistically insignificant. As shown in Model 4, in nuclear symmetry, the coefficients for salience ( $\beta$ $=641.840)$, symmetry $(\beta=-1.358)$, and their interactive term $(\beta=-774.877)$ are statistically insignificant, varying in their directions and remaining the same as those observed in Model 2 ( $\beta=764.204,-.557$, and -890.186 , respectively). These findings support the rival hypothesis that economic relations in nuclear symmetry are less likely to lead to reduced conflict.

As shown in Model 1, in strong support of the liberal hypothesis, economic relations in all dyads have a powerful and significant impact on dispute likelihood, consistent both in scale and direction. The critical finding in Model 1 is that all three dimensions of economic interdependence (trade salience $(\beta=-13.193)$, symmetry $(\beta=-1.995)$, and interdependence or their interaction terms $(\beta=-2.66))$ have powerful and statistically significant negative effects on disputes. In addition, the results from Model 1 show that both nuclear symmetric and asymmetric dyads are conflict-prone. While disputes in the nuclear asymmetric dyads are more likely as expected, the results of nuclear symmetric dyads are quite contrary to the expectations of nuclear deterrence theory.

As expected in the rival hypothesis, Model 2 reveals that the pacifying effects of economic interdependence in nuclear symmetry are not significant. On the contrary to the liberal hypothesis, salience $(\beta=763.204)$ is more likely to increase disputes, but the association is quite weak. Symmetry $(\beta=-.557)$ has a negative impact on disputes, but the relationship is very weak. In addition, interdependence, the interaction term ( $\beta=-890.186)$ of salience and symmetry, is more likely to decrease disputes, yet the relation is not strong. As shown in Model 2, when the variable of economic interdependence in the nuclear symmetric dyads is additionally included in Model 1 , nuclear symmetric dyads $(\beta=1.755)$ are more likely to increase disputes, but the relationship is quite weak. In addition, Model 2 shows that trade ties in all dyads still have a significant negative impact on disputes when those trade relations in situations of nuclear symmetry are controlled. When trade relations in nuclear symmetry are additionally included in Model 1, salience $(\beta=-12.933)$, symmetry $(\beta=-1.94)$, and their interaction term 
$(\beta=-2.654)$ in all dyads still have very a powerful and significant negative impact on disputes, strongly supporting liberal peace theory.

The results from Model 3 reveal that all three dimensions of trade relations in nuclear asymmetry are strongly associated with disputes but vary in their directions. Surprisingly, contradicting the liberal argument, salient trading relationships or balance of trade dependence is more conflict-prone than other types of relationships. The interactive effect of salience and symmetry, however, leads to significant and powerful reductions in the likelihood of conflict within dyadic relationships. When the variable of interdependence in nuclear asymmetry is additionally included in Model 1, all three dimensions of interdependence in all dyads have drastically changed in their directions, scales, and significance levels, respectively, as indicated in Model 3. This sharp change allows me to conclude with confidence that trade relations in nuclear asymmetry have a powerful impact on disputes one way or another. When trade linkages in nuclear asymmetry are additionally included in Model 1 , the statistically significant and negative coefficients for salience $(\beta=-7.651)$ and symmetry $(\beta=-2.967)$ in all dyads by and large remain the same as those observed in Model $1(\beta=-13.193$ and -1.995) and Model 2 ( $\beta=-12.933$ and -1.940), except for slight changes in their significant levels, respectively. Surprisingly, the coefficient for the combined effect $(\beta=1.115)$ of extensive and mutual dependence, however, reverses its sign from that observed in Model $1(\beta=-2.66)$ and Model $2(\beta=-2.654)$, and its statistical significance disappears completely.

The findings from the control variables offer few surprises. Dyads with one major power are more likely to engage in militarized disputes. Dyads with greater disparities of power are more likely to engage in disputes. Larger dyad size and contiguity are positively associated with the likelihood of dyadic disputes. The presence of an alliance has no statistically significant effect on the probability that dyads will engage in conflict. Disputes between democratic states are less likely. The end of the Cold War has no statistically significant effect on dispute likelihood.

In sum, in situations of nuclear asymmetry, the statistically significant positive coefficients for salience and asymmetry reveal that conflicts in those dyads with extensive and balanced dependent trade linkages appear to be more likely than in other dyads. Yet, the statistically significant and negative coefficient for dimension of interdependence, which is the combined effect of salience and symmetry, discloses that conflicts in dyads with high levels of both salience and symmetry are significantly less likely.

One last question concerns how to interpret the meaning of the coefficients for the addictive effects of salience and symmetry versus the combined effect repre- 
sented by the interdependence dimension in nuclear asymmetric dyads? According to Barbieri, "It is useful to interpret the respective coefficients of salience and symmetry when one condition is set equal to zero." (Barbieri 2002) On the one hand, it is assumed that if the value of symmetry is set to zero in a dyad, the interdependence index would be equal to zero as well. Accordingly, under these conditions, it is the coefficient for salience alone that would be relevant for evaluating the effect of trade linkages on disputes. By the same logic, on the other hand, it is assumed that the coefficient for symmetry alone would provide the estimated impact of trade linkages when salience is set equal to zero (Ibid.).

Also, the statistically significant and reverse sign of salience $(\beta=70.585)$ and symmetry $(\beta=3.659)$ to their interaction term, interdependence $(\beta=-122.244)$, demonstrates that interdependence has two reverse effects on conflict, along with different levels of salience and symmetry. Given the nonlinear nature of logit estimates, it is reasonable and possible to evaluate the overall relationship of interdependence and conflict largely through largely different levels of salience and symmetry, such as low and high. The reverse interactive effect of salience and symmetry, as represented by interdependence, on conflict could be largely clarified by generating and including variables with higher values of salience and symmetry respectively, in Model 4. The variables with higher values of salience and symmetry could be obtained with the squared values of those dimensions, named salience ${ }^{2}$ and symmetry ${ }^{2}$ respectively. Now if the coefficient for salience ${ }^{2}$ and symmetry ${ }^{2}$ respectively, were found to be negative on conflict, the negative interactive effect represented by interdependence could be interpreted to mean that high levels of both salience and symmetry would have a negative impact on conflict. On the contrary, the low level of either salience or symmetry had a positive impact on conflict.

Appendix A examines the question of whether higher levels of either salience or symmetry, as represented by salience $e^{2}$ and symmetry ${ }^{2}$ respectively, have a reverse impact on conflicts. In Appendix A, the main focus is on the direction of the sign of the coefficients for salience ${ }^{2}$ and symmetry ${ }^{2}$, not on their significance level. As expected in the negative coefficient for the interdependence dimension ( $\beta=-122.244)$ in Model 4, the coefficients for salience ${ }^{2}(\beta=-33.615)$ and symme$\operatorname{try}^{2}(\beta=-2.753)$ reverse their signs from those observed in salience $(\beta=641.133)$ and symmetry $(\beta=8.063)$ in Appendix A. Therefore, the negative signs for salience $^{2}$ and symmetry ${ }^{2}$ allow me to conclude with confidence that certain high levels of salience and symmetry have a statistically significant negative impact on conflict, while low levels of either one could have a positive impact on conflict as noted in the statistically significant positive coefficients for salience $(\beta=70.585)$ 
and symmetry $(\beta=3.659)$.

These findings from Appendix A are then integrated into those regarding nuclear asymmetry in Model 4. In nuclear asymmetric dyads, in contradiction to the expected outcome suggested by the liberal hypothesis, low levels of either salience or symmetry appear to have discernable positive effects on conflict, as indicated in the statistically significant and positive coefficient for salience $(\beta$ $=70.585)$ and symmetry ( $\beta=3.659)$ in Model 4. In addition, the high level of both salience and symmetry seems to have a negative effect on conflict, as noted in the negative coefficient for salience ${ }^{2}(\beta=-33.615)$ and symmetry $^{2}(\beta=-2.753)$ in Appendix A. On the other hand, evidence in support of the liberal argument is revealed in the high levels of both salience and symmetry. The statistically significant and negative coefficient for interdependence $(\beta=-122.244)$ suggests that high levels of both salience and symmetry ${ }^{18}$ could lead to a reduced probability of conflict when both salience and symmetry rise simultaneously to higher levels.

\section{CONCLUSION}

This paper mainly aimed to address the question of whether a liberal peace is likely in nuclear asymmetry. Employing the concepts of security gains generated through economic relations in size asymmetry, I developed an idea about the pacifying effect of interdependence in nuclear asymmetry on conflict. While the international system in nuclear asymmetry could produce highly conflict-prone and unbalanced security relations on the one hand, economic ties in nuclear asymmetry could promote peace by the sharing and exchanging of both economic and security gains which are generated only in nuclear asymmetry, on the other hand. I assume that a non-nuclear state enters into a trade alliance with a nuclear state to obtain the security that the nuclear state is capable of offering. I further assume that a nuclear state enters into trade linkages with a non-nuclear state to obtain trade gains.

Along with these assumptions, I constructed a primary liberal hypothesis with respect to nuclear asymmetry and a rival hypothesis with respect to nuclear symmetry and tested these during the period 1950-2001 using a logit statistical model. Overall, the results presented here showed that extensive and mutually

\footnotetext{
18 In Appendix I, it was proven that the coefficients for salience 2 and symmetry2 were found to be negative with respect to conflict the same as demonstrated by the negative coefficient for the interaction term represented by interdependence. Accordingly, interdependence could be interpreted as the combined effect at high levels of both salience and symmetry.
} 
dependent trade relations decrease significantly the likelihood that dyads would engage in militarized dispute, in strong empirical support of the liberal hypothesis. In addition, this analysis showed that both nuclear symmetric and asymmetric dyads are conflict-prone.

Is a liberal peace likely in situations of nuclear asymmetry? Clearly, the results support the notion that economic relations in nuclear asymmetry have a significant effect in reducing the likelihood of dyadic disputes but only when the trading linkages are especially valuable, extensive, and mutually dependent. In nuclear asymmetric dyads, on the one hand, evidence in support of the liberal argument is revealed in the high levels of both salient and symmetrical trade ties. On the other hand, in contradiction to the liberal hypothesis, low levels of either salient or symmetrical trade linkages appear to lead to an increased probability of conflict. To capture negative evidence for the liberal hypothesis in nuclear asymmetric dyads, I also constructed and examined a rival hypothesis that the effects of trade linkages on conflict in nuclear symmetric dyads were less likely to lead to reduced conflict. As expected, the overall results reveal that economic relations in nuclear symmetry have an insignificant effect on conflict.

The theoretical implications of these findings are quite significant and straightforward, further challenging the realist claims that economic interdependence has minimal systematic influence on conflict. Furthermore, economic relations substantially dampen hostilities in conflict-prone states as shown in situations of nuclear asymmetry, which reflects the extreme vulnerability of relations in the current international system. In addition, these findings are consistent with those in previous research (Oneal, H. Oneal, Maoz, and Russett 1996). In sum, this paper clearly demonstrates the utility of the liberal peace claim, particularly in relations between conflict-prone states.

These findings have significant practical implications particularly for such nuclear asymmetric relations as those between the two Koreas. In the nuclear era, the sad truth is that an absolute majority of countries have no option but to live with nuclear states. Obviously, peace is not given, but rather is created by the will of people. The findings reveal that, while countries in situations of nuclear asymmetry are highly conflict-prone, those countries also have considerable opportunities to promote peace by expanding economic ties, which can generate both economic and security gains for everyone.

The findings presented here have several important theoretical implications for future research on the study of trade and conflict in situations of nuclear asymmetry. First, I assume that a non-nuclear state enters into a trade alliance with a nuclear state to obtain the security that a nuclear state is capable of offering. To maximize its security, a non-nuclear state could attempt to form trade alliances 
with more nuclear states, particularly as there are now so many nuclear states in the international system. Accordingly, it is necessary to empirically test whether trade linkages with more nuclear states will lead non-nuclear states to gain security benefits. Second, I have examined the likelihood of the liberal peace to produce positive results in situations of nuclear asymmetry, utilizing a large- $\mathrm{N}$ analysis. To bolster this quantitative analysis, it is necessary to investigate the likelihood of liberal peace success in conflict reduction by using case study analysis. A case worth investigating is the two Koreas in nuclear asymmetry. It is theoretically significant to investigate whether or not conflicts are less likely as economic relations expand. Finally, as another aspect of trade ties, it is necessary to analyze the effect of trade blocs, such as those formed by multilateral free trade agreements, on conflict in situations of nuclear asymmetry.

\section{REFERENCES}

Barbieri, Katherine. 2002. The Liberal Illusion. Ann Arbor: University of Michigan Press.

. 1996. "Economic Interdependence: A Path to Peace or a Source of Interstate Conflict." Journal of Peace Research 33(1), 29-49.

Barbieri, Katherine and J. S. Levy. 1999. "Sleeping with the Enemy: The Impact of War on Trade." Journal of Peace Research 36(4), 463-479.

Beck, Nathaniel, Jonathan N. Katz, and Richard Tucker. 1998. "Taking Time Seriously: Time-Series-Cross-Section Analysis with a Binary Dependent Variable.” American Journal of Political Science 42(4), 1260-1288.

Bennett, D. Scott and Allan C. Stam. 2000. "Research Design and Estimator Choices in the Analysis of Interstate Dyads: When Decision Matter." Journal of Conflict Resolution 44, 653-685.

Bennett, D. Scott, \& Allan Stam. 2000. "EUGene: A Conceptual Manual." International Interactions 26, 179-204. . 2004. The Behavioral Origins of War. Ann Arbor: The University of Michigan Press.

Benson, Michelle A. 2005. "The Relevance of Politically Relevant Dyads in the Study of Interdependence and Dyadic Disputes." Conflict Management and Peace Science 22, 113-133.

Bremer, Stuart A. 1992. "Dangerous dyads: Conditions affecting the likelihood of interstate war, 1816-1965." Journal of Conflict Resolution 36, 309-341.

Bueno de Mesquita, Bruce and William H. Riker. 1982. "An Assessment of the Merits of Selective Nuclear Proliferation.” The Journal of Conflict Resolution 
26(2), 283-306.

Bueno de Mesquita, Bruce and D. Lalman. 1992. War and Reason: Domestic and International Imperatives. New Haven, CT: Yale University Press.

Brodie, Bernard Brodie. "Changing Capabilities and War Objectives.” 1952. Bernard Brodie Papers, Box 12, UCLA Library.

Coale, Ansley J. 1985. "Nuclear War and Demographers' Projections." Population and Development Review 11(3), 483-493.

Danilovic, Vesna. 2002. When the Stakes Are High: Deterrence and Conflict among Major Powers. Ann Arbor: University of Michigan Press.

DeNardo, James. 1995. The Amateur Strategist: Intuitive Deterrence Theories and the Politics of the Nuclear Arms Race. New York: Cambridge University Press.

Dixon, William J. 1994. "Democracy and the Peaceful Settlement of International Conflict.” American Political Science Review 88(1), 14-32.

Domke, William K. 1988. War and the Changing Global System. New Haven: Yale University Press.

Friedrich, Robert J. 1982. "In Defense of Multiplicative Terms in Multiple Regression Equations.” American Journal of Political Science 26(4), 797833.

Gartzke, Erik and Mattew Kroenig. 2009. "A Strategic Approach to Nuclear Proliferation.” Journal of Conflict Resolution 53, 151-16o.

Gartzke, Erik and Dong-Joon Jo. 2007. "Determinants of Nuclear Weapons Proliferation: A Quantitative Model.” Journal of Conflict Resolution 5(1), 167-194.

Gaddis, Lewis John. 1986. “The Long Peace: Elements of Stability in the Postwar International System.” International Security 10, 99-142

Gasiorowski, Mark J. 1986. "Economic Interdependence and International Conflict: Some Cross-National Evidence.” International Studies Quarterly 30, 39-57.

Gasiorowski, Mark J. and Solomon W. Polachek. 1982. "Conflict Interdependence: East-West Trade and Linkages in the Era of Détente.” Journal of Conflict Resolution 26(4), 709-729.

Gelpi, Christopher F. and Joseph M. Grieco. 2008. "Democracy, Interdependence, and the Sources of the Liberal Peace.” Journal of Peace Research 45(1), 17-36.

Gilpin, Robert. 1987. The Political Economy of International Relations. Princeton, NJ: Princeton University Press.

Glaser, Charles L. 1992. "Nuclear Policy without an Adversary." International Security 16(4), 34-78. 
Gleditsch, Kristian Skrede. 2002. "Expanded Trade and GDP Data." Journal of Conflict Resolution 46, 712-724.

Gowa, Joanne and Edward D. Mansfield. 1993. "Power Politics and International Trade.” American Political Science Review 87(2), 408-420.

Gowa, Joanne. 1994. Allies, Adversaries, and International Trade. New Jersey: Princeton University Press.

Hegre, Havard. 2004. "Size Asymmetry, Trade, and Militarized Conflict." The Journal of Conflict Resolution 48(3), 403-429.

. 2000. "Development and the Liberal Peace: What Does it Take to be a Trading State?” Journal of Peace Research 37(1), 5-30. . 2004. "Size Asymmetry, Trade, and Militarized Conflict." The Journal of Conflict Resolution 48(3), 403-429.

Hegre, Havard, John R. Oneal and Bruce Russett. 2010. "Trade Does Promote Peace: New Simultaneous Estimates of the Reciprocal Effects of Trade and Conflict." Journal of Peace Research 47(6), 763-774.

Huth, Paul. 1990. "The Extended Deterrence Value of Nuclear Weapons." Journal of Conflict Resolution 34(2), 270-290.

Huth, Paul and Bruce Russett. 1993. "General Deterrence between Enduring Rivals: Testing Three Competing Models." American Political Science Review 87, 61-73.

. 1984. "What Makes Deterrence Work? Cases from 1900-1980." World Politics 36, 496-526.

James D. Morrow. 1991. "Alliance and Asymmetry: An Alternative to the Capability Aggregation Model of Alliances." American Journal of Political Science 35(4), 904-933.

Jones, Daniel M., Stuart A. Bremer, and J. David Singer. 1996. "Militarized Interstate Disputes, 1816-1992: Rationale, Coding Rules, and Empirical Patterns." Conflict Management and Peace Science 15(2), 163-213.

Kant, Immanuel. 1957. Perpetual Peace. Indianapolis: Bobbs-Merrill.

Keohane, Robert O. and Joseph S. Nye. 1989. Power and Interdependence: World Politics in Transition. Boston, MA: Little, Brown.

Keshk, Omar M. G., Brian M. Pollins, and Rafael Reuveny. 2004. "Trade Still Follows the Flag: The Primacy of Politics in a Simultaneous Model of Interdependence and Armed Conflict." The Journal of Politics 66(4), 1155-1179.

Kim, Hyung Min and David L. Rousseau. 2005. "The Classical Liberals Were Half

Right (or Half Wrong): New Tests of the Liberal Peace, 1960-88." Journal of Peace Research 42(5), 523-643.

Kroll, John A. 1993. “The Complexity of Interdependence.” International Studies 
Quarterly 37(2), 321-348.

Kugler, Jacek. 1984. “Terror without Deterrence.” Journal of Conflict Resolution 28, 470-506.

Kugler, Jack and Douglas Lemke. 1996. Parity and War. Ann Arbor, MI: University of Michigan Press.

Lebow, Richard Ned and Janice Gross Stein. 1989. "Rational Deterrence Theory: I Think, Therefore I Deter.” World Politics 41(2), 208-224.

Mansfield, Edward E. 1994. Power, Trade, and War. NJ: Princeton University Press.

Mansfield, E. D. and B. M. Pollins. 2001. "The Study of Interdependence and Conflict." Journal of Conflict Resolution 45(6), 834-859.

Mansfield, E. D. and John C. Pevehouse. 2000. "Trade Blocs, Trade Flows, and International Conflict.” International Organization 54(4), 775-808.

Maoz, Zeev. 2009. "The Effects of Strategic and Economic Interdependence on International Conflict across Levels of Analysis." American Journal of Political Science 53(1), 223-240.

Maoz, Zeev and Bruce Russett. 1993. "Normative and Structural Causes of Democratic Peace, 1946-1986.” American Political Science Review 87(3), 624-638.

Marshall, Monty G., Keith Jaggers and Ted Robert Gurr. 2011. Polity IV Project: Dataset Users' Manual. Arlington: Polity IV Project.

Mearsheimer, John J. 1990. "Back to the Future: Instability in Europe after the Cold War." International Security 15(1), 50-66.

Michael F. Altfeld. 1984. "The Decision to Ally: A Theory and Test." The Western Political Quarterly 37(4), 523-544.

Michael W. Simon and Erik Gartzke. 1996. "Political System Similarity and the Choice of Allies: Do Democracies Flock Together, or Do Opposites Attract?" The Journal of Conflict Resolution 40(4), 617-635.

Mueller, John. 2010. Atomic Obsession: Nuclear Alarmism from Hiroshima to Al Qaeda. New York: Oxford University Press.

. 2009. "War Has Almost Ceased to Exist: An Assessment." Political Science Quarterly 124(2), 297-321.

. 2004. "What Was the Cold War About? Evidence from Its Ending." Political Science Quarterly 119(4), 609-631.

Mueller, John. 1988. "The Essential Irrelevance of Nuclear Weapons: Stability in the Postwar World.” International Security 13(2), 55-79.

J. Scott Long. 1997. Regression Models for Categorical and Limited Dependent Variables. California: SAGE Publications, Inc.

Oneal, John R. and Bruce M. Russett. 1999. "Assessing the Liberal Peace with 
Alternative Specifications: Trade Still Reduces Conflict." Journal of Peace Research 36(4), 423-442.

. 1999. "The Kantian Peace: The Pacific Benefits of Democracy, Interdependence, and International organizations." World Politics 52(1), 1-37.

. 1997. "The Classical Liberals Were Right: Democracy, Interdependence, and Conflict, 1950-1985." International Studies Quarterly 41, 267-294.

Oneal, John R., Frances H. Oneal, Zeev Maoz, and Bruce Russett. 1996. "The Liberal Peace: Interdependence, Democracy, and International Conflict, 1950-85." Journal of Peace Research 33(1), 11-28.

Organski, A. F. K. and Jacek Kugler. 1980. The War Ledger. Chicago: University of Chicago Press.

Papayoanou, Paul A. 1996. "Interdependence, Institutions, and the Balance of Power: Britain, Germany, and World War I.” International Security 20, 42-76.

Polachek, Solomon W. 1980. "Conflict and Trade." Journal of Conflict Resolution 24(1), 57-78.

. 1997. "Why Do Democracies Cooperate More and Fight Less: The Relationship between International Trade and Cooperation." Review of International Economics 5(3), 295-309.

Polachek, Solomon W., J. Robst, and Y.C. Chang. 1999. "Liberalism and Interdependence: Extending the Trade-Conflict Model." Journal of Peace Research 36(4), 405-422.

Pollins, Brian M. 1989. "Conflict, Cooperation and Commerce: The Effect of International Political Interactions on Bilateral Trade Flows.” American Journal of Political Science 33, 737-761.

. 1989. "Does Trade Still Follow the Flag?" American Political Science Review 83(2), 465-480.

Rauchhaus, Robert. 2009. "Evaluating the Nuclear Peace Hypothesis: A Quantitative Approach." Journal of Conflict Resolution 53(2), 258-277.

Reuveny, Rafael. 2003. "Measuring Conflict and Cooperation: An Assessment." In Edward D. Mansfield and Brian M. Pollins eds., Economic Interdependence and International Conflict: New Perspectives on an Enduring Debate. Ann Arbor: University of Michigan Press, 254-269.

Reuveny, Rafael and Heejoon Kang. 1998. "Bilateral Trade and Political Conflict/Cooperation: Do Goods Matter?” Journal of Peace Research 35, 581-602.

. 1996. "International Trade, Political Conflict/Cooperation, and Granger Causality.” American Journal of Political Science 40, 943-970. 
Rosecrance, Richard. 1986. The Rise of the Trading State: Commerce and Conquest in the Modern World. New York: Basic Books.

Russett, Bruce and J. Oneal. 2001. Triangulating Peace. NY: W. W. Norton \& Company, Inc.

Russett, Bruce M., John R. Oneal, and David R. Davis. 1998. "The Third Leg of the Kantian Tripod for Peace: International Organizations and Militarized Disputes, 1950-1985." International Organization 52(3), 441-467.

Sagan, Scott D. 1995. "More Will Be Worse." In Scott D. Sagan and Kenneth N. Waltz ed., The Spread of Nuclear Weapons: A Debate. New York; W.W. Norton \& Company, 48-91.

Sagan, Scott D. \& Waltz, Kenneth. N. 1995. The Spread of Nuclear Weapons: a Debate. NY: W.W. Norton.

Sarkees, Meredith, Frank Wayman, and J. David Singer. 2003. "Inter-State, Intra-State, and Extra-State War: A Comprehensive Look at Their Distribution over Time, 1816-1997." International Studies Quarterly 32, 49-70.

Siverson, Randolph M. and Harvey Starr. 1991. The Diffusion of War. Ann Arbor, MI: University of Michigan Press.

Solingen, Etel. 1998. Regional Orders at Century's End: Global and Domestic Influences on Grand Strategy. New Jersey: Princeton University Press.

Starr, Harvey and B. A. Most. 1976. "The Substance and Study of Borders in International Relations Research.” International Studies Quarterly 20, 581-620.

Trachtenberg, Marc. 1989. “Strategic Thought in America, 1952-1966.” Political Science Quarterly 104(2), 301-334.

Waltz, Kenneth N. 1995. "More May Be Better." In Scott D. Sagan and Kenneth N. Waltz ed., The Spread of Nuclear Weapons: A Debate. New York; W.W. Norton \& Company, 1-47. . 1993. "The Emerging World Structure of International Politics." International Security 18, 44-79. . 1990. "Nuclear Myths and Political Realities." The American Political Science Review 84(3), 731-745.

Zagare, Frank C. and D. Marc Kilgour. 2000. Perfect Deterrence. New York: Cambridge University Press 
Is Liberal Peace Likely in N udear Asymmetry? | 61

Appendix A. Duration Dependent Logits and the Onset of Dyadic Disputes: 1950-2001

\begin{tabular}{|c|c|c|}
\hline Variable & Coefficients & Standard Errors \\
\hline \multicolumn{3}{|l|}{ 1) In all dyads } \\
\hline Salience & $-6.432^{*}$ & 2.713 \\
\hline Symmetry & $-3.022^{* * *}$ & 0.799 \\
\hline Interdependence & 1.719 & 1.01 \\
\hline Nuclear symmetry dyads & 3.286 & 27.188 \\
\hline Nuclear asymmetry dyads & -4.306 & 3.251 \\
\hline \multicolumn{3}{|l|}{ 2) In nuclear symmetry dyads } \\
\hline Salience & 641.133 & 2065.429 \\
\hline Symmetry & -1.398 & 27.232 \\
\hline Interdependence & -773.931 & 2073.047 \\
\hline \multicolumn{3}{|c|}{ 3) In nuclear asymmetry dyads } \\
\hline Salience & 93.313 & 66.331 \\
\hline Symmetry & 8.063 & 6.35 \\
\hline (Salience)2 & -33.615 & 162.834 \\
\hline (Symmetry)2 & -2.753 & 3.322 \\
\hline Interdependence & $-150.522^{*}$ & 67.269 \\
\hline Major power & $1.091^{* * *}$ & 0.078 \\
\hline Relative capabilities & $-1.526^{* * *}$ & 0.1 \\
\hline Dyad size & $1.80 \mathrm{e}-13^{* * *}$ & $1.69 \mathrm{e}-14$ \\
\hline Contiguity & $2.919^{* * *}$ & 0.043 \\
\hline Alliance & -0.035 & 0.019 \\
\hline Joint democracy & $-0.008^{\star \star *}$ & 0.001 \\
\hline Post-Cold War & -0.042 & 0.048 \\
\hline Peace-year & $-0.396^{* * *}$ & 0.013 \\
\hline spline1 & $-0.003^{\star \star *}$ & 0.000 \\
\hline spline2 & $0.001^{* * *}$ & 0.000 \\
\hline spline3 & $-0.000^{\star \star *}$ & 0.000 \\
\hline Constant & $-1.704^{*}$ & 0.8 \\
\hline Observation number & 846626 & \\
\hline LR chi2(14) & 12172.16 & \\
\hline Prob> chi2 & 0.00 & \\
\hline Log likelihood & -15624.501 & \\
\hline Pseudo R2 & 0.2803 & \\
\hline
\end{tabular}

${ }^{*} p<0.05,{ }^{* *} p<0.01,{ }^{* * *} p<0.001$ 